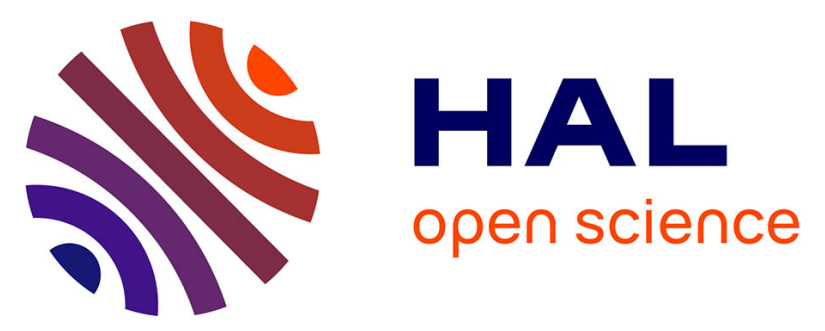

\title{
Loss of crystalline structure and swelling kinetics of maize starch and flour granules in glycerol excess: The role of the envelope structure
}

\author{
Florian Démé, Edith Peuvrel-Disdier, Bruno Vergnes
}

\section{To cite this version:}

Florian Démé, Edith Peuvrel-Disdier, Bruno Vergnes. Loss of crystalline structure and swelling kinetics of maize starch and flour granules in glycerol excess: The role of the envelope structure. Industrial Crops and Products, 2015, 70, pp.149-157. 10.1016/j.indcrop.2015.03.037 . hal-01137224

HAL Id: hal-01137224

https://hal-mines-paristech.archives-ouvertes.fr/hal-01137224

Submitted on 13 Apr 2017

HAL is a multi-disciplinary open access archive for the deposit and dissemination of scientific research documents, whether they are published or not. The documents may come from teaching and research institutions in France or abroad, or from public or private research centers.
L'archive ouverte pluridisciplinaire HAL, est destinée au dépôt et à la diffusion de documents scientifiques de niveau recherche, publiés ou non, émanant des établissements d'enseignement et de recherche français ou étrangers, des laboratoires publics ou privés. 


\title{
Loss of crystalline structure and swelling kinetics
}

\section{of maize starch and flour granules in glycerol excess:}

\section{the role of the envelope structure}

\author{
F. Démé ${ }^{+}$, E. Peuvrel-Disdier, B. Vergnes * \\ MINES ParisTech, PSL Research University, CEMEF - Centre de Mise en Forme des \\ Matériaux, CNRS UMR 7635, \\ CS 10207, rue Claude Daunesse, 06904 Sophia Antipolis Cedex (France)
}

* Corresponding author: B. Vergnes

bruno.vergnes@mines-paristech.fr

(33) 493957463

+ Present address: Laboratoire de Recherches et de Contrôle du Caoutchouc et des Plastiques, 60 Rue Auber, 94408 Vitry sur Seine Cedex, France 
Abstract: Temperatures of loss of crystallinity and kinetics of swelling in glycerol excess were investigated on various maize flours and starch. The increase of amylose content in flour leads to a more persistent "crystalline" structure. This appears more clearly in differential scanning calorimetry (DSC) than in loss of birefringence, because a significant portion of the starch structure does not come only from amylopectin crystallites but also from helical arrangements. The effect of heating rate on the loss of order and on the glycerol/starch interactions was highlighted. Granule swelling tests in glycerol excess confirmed that the melting of crystallites is not a sufficient condition for complete dissolution of the granule. The granule swelling takes place in two steps for flours containing amylose, and occurs largely after gelatinization due to the importance of the granule envelope. The strength of this envelope, due to the presence of networks including proteins, lipids and amylose, is different between standard maize flour and starch. Tests in presence of lauric acid highlight the role of lipids on the granule envelope strength. The change in the viscosity of the granule/glycerol suspension during gelatinization is explained by granule swelling and can be described by a Krieger-Dougherty equation.

KEY WORDS: Maize flour, Starch, Glycerol, Swelling, Amylose, Crystallinity. 


\section{Introduction}

2 Starch gelatinization has been studied for a long time (Olkku and Rha, 1978; Donovan, 1979;

3 Ratnayake and Jackson, 2008), essentially in water, but also more recently in other liquids, like

4 glycerol (Liu et al., 2011), NMMO (Koganti et al., 2011, 2015) and ionic liquids (Liu and Budtova,

5 2013; Mateyawa et al., 2013). Different methods were used to characterize gelatinization kinetics

6 and mechanisms, like differential scanning calorimetry (DSC), optical and electron microscopy,

7 birefringence, wide angle X-ray diffraction, light scattering, viscosity measurements. DSC is one of

8 the most popular and was largely used to explore the phase transitions in starch/water systems

9 (Wootton and Bamunuarachchi, 1979; Russell, 1987; Zanoni et al., 1995; Spigno et al., 2004;

10 Sopade et al., 2004). Combinations of rheology and microscopy can also be used (Tan et al., 2008).

11 It is reported that suspension viscosity increases during gelatinization, then reaches a peak and 12 decreases (Eliasson, 1986; Yang and Rao, 1998; Yu et al., 2006). By studying starches of different 13 botanical origins or with various amylose/amylopectin ratios, it was possible to evidence the strong 14 influence of this parameter (Russell, 1987; Tester and Morrison, 1990; Cooke and Gidley, 1992; 15 Jenkins and Donald, 1998; Fredriksson et al., 1998; Liu et al., 2006; Chen et al., 2007; Blazek and 16 Copeland, 2008; Liu et al., 2011; Chen et al., 2011). It was shown that the amylose content is very 17 influent on granule swelling in water excess. The granule size, the heating rate (Patel and 18 Seetharaman, 2006) and the addition of fatty acids (Blazek and Copeland, 2009) can also change 19 granule swelling kinetics. Theses fatty acids do not have the same interactions with maize starches 20 of different amylose content (Chang et al., 2013). Some explanations of the differences in swelling 21 kinetics regardless to the amylose content were proposed by Debet and Gidley (2006, 2007). They 22 evidenced the role of the granule envelope structure on the swelling behaviour. This structure is due 23 to a network made of proteins and V-type crystallites, resulting from helical arrangements of 24 amylose chains. The recent development of plasticized starch/thermoplastic blends (St-Pierre et al., 25 1997; Rodriguez-Gonzalez et al., 2003; Li and Favis, 2010), based on ternary starch/glycerol/water 
mixtures, recently led to the study of starch gelatinization in such media (Forssell et al., 1997;

27 Nashed et al., 2003; Tan et al., 2004; Li et al., 2008; Liu et al., 2011). If the gelatinization of starch is well documented, it is less the case for flours. However, from an economic point of view, flour is less expensive than starch to be used in blend with a thermoplastic. Consequently, it is also interesting to look at flours behavior. Therefore, in the present study, we propose to characterize the mechanism of starch and flour gelatinization in glycerol suspensions, and to evaluate the swelling kinetics of starch and flour granules with different amylose/amylopectin contents in pure glycerol.

\section{Materials and methods}

Four starchy products, kindly provided by ULICE (Riom, France), were investigated in this study: three maize flours (standard, waxy, high amylose) and a standard maize starch. SEM pictures of these materials are shown in Figure 1 and their main characteristics are given in Table 1 . They differed either by the variety and/or the treatment, e.g. extraction of fats and proteins for the starch. The three varieties of maize flour essentially differed by their respective ratio of amylose and maize contained about $30 \mathrm{wt} \%$, and high amylose maize (or amylomaize) $70 \mathrm{wt} \%$. The initial water content was also different for the various starchy products: it varied from $8.4 \mathrm{wt} \%$ (waxy flour) to excess. Experiments at the same water content may have been of interest, but were not carried out in the present study. Storage in closed bags of the samples in a freezer allowed to avoid changes in water content. It was effectively checked that the storage did not modify the water content. The global gelatinization process in glycerol excess is assumed to be not affected by small variations of the water content. This is of course fully different from plasticization of starch at low glycerol content, where small variations of the water content have an important effect on the plasticization process and the product rheological behavior. The lipid content in flours was globally proportional 
to the amylose amount. The protein content was almost zero in standard starch whereas it was quite

51 high in flours (around $9 \mathrm{wt} \%$ ).

52 Glycerol was chosen as starchy phase plasticizer. Its melting temperature was $17^{\circ} \mathrm{C}$, it is boiling at

$53290^{\circ} \mathrm{C}$, but may begin to evaporate around $170^{\circ} \mathrm{C}$. It had a density of 1.26 and a viscosity of 1 Pa.s 54 at $25^{\circ} \mathrm{C}$.

55 Lauric acid was also used in the study. It is a mono-fatty acid, with a melting temperature around $56 \quad 45^{\circ} \mathrm{C}$. It has no double bond and can create complexes with amylose.

57 Microscopic observations were performed on a Leitz microscope (Metallux 3), equipped with a CCD camera (JVC KY-F75U). Observations in polarized light were made with a hot stage (Linkam TMS 91) on a very dilute suspension of dry flour in glycerol, to estimate the temperature of loss of

60 crystallinity (Maltese cross extinction) and to observe the swelling of the granules with the 61 temperature.

62 Viscosity measurements under continuous shear of suspensions of granules in glycerol were carried 63 out on a parallel plate rheometer (Stresstech ${ }^{\odot}$, Reologica). $40 \mathrm{~mm}$ diameter plates and a $1 \mathrm{~mm}$ gap 64 were used. The initial volume fraction of flour or starch varied between 6.3 and $6.6 \mathrm{wt} \%$ ( $2 \mathrm{~g}$ of 65 starch or flour suspended in $40 \mathrm{~mL}$ of glycerol). After a pre-shear at $25 \mathrm{~s}^{-1}$ to break eventual 66 aggregates, the suspension was sheared at $16 \mathrm{~s}^{-1}$, with a heating rate in the range 1 to $10^{\circ} \mathrm{C} / \mathrm{min}$.

67 Calorimetric analyzes were performed on a differential scanning calorimeter (Perkin Elmer DSC7).

68 To avoid loss of material (water evaporation), high pressure sealed capsules were used.

\section{3. Results and discussion}

\subsection{Gelatinization in glycerol excess}

71 We first analyzed the temperatures of loss of crystallinity in excess of glycerol. The loss of crystallinity can be characterized by the loss of birefringence in optical microscopy and by the appearance of a melting endotherm in DSC experiments. For the loss of birefringence, a suspension 
of granules (flour or starch) in glycerol was observed in optical microscopy, under polarized light (Fig. 2). For DSC experiments, the mixture contained $40 \mathrm{wt} \%$ flour (or starch) and $60 \mathrm{wt} \%$ glycerol. Indeed, the quantity of starchy phase had to be significant in order to obtain a signal. Moreover, above $50 \%$ glycerol, its amount has almost no influence on the gelatinization temperature (Van Soest et al., 1996, Habeych et al., 2009). In both cases (microscopy and DSC), the heating rate was $10^{\circ} \mathrm{C} / \mathrm{min}$.

Values of temperature of loss of cristallinity, obtained by both microscopy and DSC are indicated in Table 2. Values for the beginning of gelatinization are similar for all products, although high amylose maize flour presents a higher melting temperature. In fact, both techniques do not detect the same phenomena. Temperature range of gelatinization observed by optical microscopy corresponds to the loss of birefringence due to the melting of crystallites. In comparison, melting endotherms measured by DSC are due to both loss of crystallinity and dissociation of double helices formed by amylose/lipid complexes (Cooke and Gidley, 1992). In addition, melting endotherms of crystallites and amylose/lipid complexes (more stable) can be merged (Jenkins and Donald, 1998, Matveev et al., 2001, Liu et al., 2006), explaining that the melting temperature range seen by DSC is wider than the one seen by optical microscopy. The higher lipid content in high amylose flour explains its broader melting endotherm $\left(35^{\circ} \mathrm{C}\right)$ relatively to waxy maize $\left(20^{\circ} \mathrm{C}\right)$. In addition, the melting enthalpy increases with amylose content, while the degree of crystallinity is often lower for high amylose starches (Tester et al., 2004). In our case, the degree of crystallinity deduced from XRD experiments was $16.5 \%, 21.8 \%$ and $24.8 \%$ for high amylose, standard and waxy flours, respectively. This highlights the role of amylose content on a more persistent structure, mainly due to more stable amylose/lipid complexes.

For each sample, we also observed an exotherm just before the melting endotherm (around $50^{\circ} \mathrm{C}$ in Fig. 3). This exotherm is linked to the formation of hydrogen bonds between starch and polyols such as glycerol (Van Soest et al., 1996, Smits et al., 2003, Habeych et al., 2009). This peak is only 
observed at low water content in water/glycerol/starch mixtures. Indeed, too much water saturates

100 the hydroxyl groups of starch chains, making it impossible to link starch and glycerol (Habitante et 101 al., 2008). As for gelatinization, the transition corresponding to this peak is irreversible: nothing is observed on cooling, or during a second scan (Fig. 3).

103 The location of these two peaks (endotherm and exotherm) changes when increasing the heating 104 rate from $1^{\circ} \mathrm{C} / \mathrm{min}$ to $5^{\circ} \mathrm{C} / \mathrm{min}$. Fig. 4 depicts the variation of the peak temperatures with the heating 105 rate. The temperature of the endotherm peak increases slightly with the heating rate (from 113 to $106126^{\circ} \mathrm{C}$ ), whereas the exotherm one shows a stronger dependence (from 46 to $85^{\circ} \mathrm{C}$ ). The melting 107 temperature of the crystals should not depend on the heating rate. The small increase of the 108 temperature of the melting endotherm with the heating rate can be interpreted as a little overheating 109 although a $10^{\circ} \mathrm{C} / \mathrm{min}$ heating rate is usually chosen to avoid this phenomenon. As mentioned above, 110 the exotherm is due to another physical phenomenon. Assuming that it is linked to starch/glycerol 111 interactions, the diffusion of glycerol into starch granules must be essential in these interactions and 112 this phenomenon is thermally activated. In addition, some annealing effects on heating could not be 113 excluded. These measurements evidence a different effect of the heating rate on the two physical 114 phenomena.

115 To validate the physical interpretation for the exothermic peak, the starch suspension was left at $11625^{\circ} \mathrm{C}$ for 7 days. Glycerol had thus time to diffuse into starch granules and form hydrogen bonds. 117 Accordingly, maturation of the mixture leads to the suppression of this exothermic peak (Fig. 5) and 118 the gelatinization temperature was shifted to a lower value. Smits et al. (2003) similarly reported the 119 disappearance of the exotherm on dehydrated amorphous amylopectin/glycerol mixtures after 120 storage at $20^{\circ} \mathrm{C}$ for 7 days. 


\subsection{Microscopic observations of starch and flour swelling}

125 The loss of crystallinity is a necessary but not sufficient condition to characterize the destruction of

126 the granular structure. We also measured kinetics of swelling of flour and starch granules, as the 127 swelling behavior depends on the starch structure.

128 Figure 2 shows the behavior of flour granules suspended in glycerol, with a heating rate of $5^{\circ} \mathrm{C} / \mathrm{min}$, 129 observed by optical microscopy between crossed polarizers. The Maltese cross reflects the semi130 crystalline structure of starch granules at low temperature. Granules start to swell just before the 131 loss of crystallinity. The gelatinization takes place over a temperature range of 10 to $20^{\circ} \mathrm{C}$, at 132 around $130^{\circ} \mathrm{C}$, with a gradual disappearance of the Maltese cross.

133 In the case of standard and high amylose maize flours, swelling took place in two stages: a first 134 stage where large granules (diameter $\approx 20 \mu \mathrm{m}$ ) swell just after gelatinization, and a second stage, 135 beyond $150^{\circ} \mathrm{C}$, where small granules (diameter $\approx 5 \mu \mathrm{m}$ ) started to swell whereas larger ones 136 continued to swell. Waxy maize flour and standard maize starch did not exhibit this behavior. 137 Above a certain temperature, granules became less apparent: they are usually referred to as "ghosts" 138 (Fig. 2d). Thermal disturbance of the solution above $170^{\circ} \mathrm{C}$ make the observation of the bursting of 139 these granules unclear. Nevertheless, it occurred around $180^{\circ} \mathrm{C}$ and they fully disappeared at $200^{\circ} \mathrm{C}$. 140 From these observations, it was possible to plot the evolution of the granule diameter as a function 141 of temperature (Fig. 6). Measurements of the diameters were carried out on a tenth of granules of 142 each type and size range, using an image analysis software. We observe an important increase of 143 diameter above $130-140^{\circ} \mathrm{C}$, i.e. after gelatinization.

\section{3.3. Rheological measurements during starch and flour swelling}

145 Stability tests over time were carried out at room temperature and at different shear rates to ensure 146 that suspensions do not have a thixotropic behavior. Each suspension was first pre-sheared at $25 \mathrm{~s}^{-1}$ 
147 for $60 \mathrm{~s}$ to disperse aggregates of granules. It was then subjected to a constant shear rate of $16 \mathrm{~s}^{-1}$

148 while temperature was increased with time from 25 to $200^{\circ} \mathrm{C}$, at a constant heating rate.

149 The variation of the viscosity of a suspension of standard maize flour in glycerol with temperature

150 is shown in Fig. 7. Whereas glycerol viscosity regularly decreases with temperature increase, the

151 flour suspension shows a different behavior. Initially, the viscosity of the suspension is very close to

152 that of glycerol, due to the low volume fraction of the dispersed phase (6.5 vol \%). However, after

153 gelatinization, the swelling, first of the granules and then of "ghosts", results in a sharp increase in

154 the volume fraction and therefore in the viscosity of the suspension. A two-stage process is 155 observed in the rise in viscosity, corresponding to optical microscopy observations. The first 156 viscosity increase should correspond to the swelling of large granules whereas the second step is 157 attributed to the swelling of small granules. The drop in viscosity at the end of the measurement 158 corresponds to the rupture of the "ghosts": the suspension is then transformed into a solution.

159 As we can see in Fig. 7, the viscosity evolution is affected by the heating rate. The first viscosity 160 increase, corresponding to the swelling of large granules, is clearly influenced by the heating rate. 161 Swelling at a high heating rate begins at a higher temperature. This is in agreement with the fact 162 that swelling of large granules occurs just after the gelatinization, whose temperature increases as 163 the heating rate is increased (see Fig. 4). Differences of swelling kinetics with heating rate were also 164 reported by Patel and Seetharaman (2006) in the case of water. They explained that granule 165 swelling occurred at a higher temperature at higher heating rates, what is coherent with our 166 observations.

167 The rheological behavior of all flour or starch suspensions in glycerol was later measured at the 168 same heating rate $\left(5^{\circ} \mathrm{C} / \mathrm{min}\right)$. Measurements for the different maize flour suspensions are compared 169 in Fig. 7. This figure shows that the flour amylose content has a huge effect on the swelling 170 properties of the granules. The swelling is delayed to higher temperatures and the swelling intensity 171 (evidenced as the viscosity increase) decreases as the amylose content increases. Granules of high 
amylose maize flour swell regularly and homogeneously. Numerous studies of starch swelling in

173 water reported similar results on the correlation between swelling properties and amylose content 174 but with a single-step swelling kinetics (Tester and Morrison, 1990; Sasaki and Matsuki, 1998; 175 Tester et al., 2000; Patel and Seetharaman, 2006; Chen et al., 2007; Blazek and Copeland, 2008). 176 The reduced swelling of enriched amylose starches was attributed to the presence of amylose/lipid 177 complexes in the granules. Debet and Gidley (2006) noticed that cleaning the surface of standard 178 maize granules allowed a more rapid swelling, but did not change the kinetics for high amylose 179 maize. They deduced that proteins and phospholipids, rather than amylose, could play a role. 180 However, other studies demonstrated that proteins and phospholipids are not sufficient to preserve 181 the integrity of starch granules without amylose (Debet and Gidley, 2006). The most probable 182 explanation is that, during lixiviation, proteins present on the granule surface limit the diffusion of 183 amylose chains. These amylose chains may complex and form a network with the phospholipids on 184 the granule surface. Granule swelling would thus result from a competition between starch/glycerol interactions, leading to swelling, and the strength of the network created at the surface by proteins 186 and amylose/lipid complexes. The fact that small granules present a reduced swelling after 187 gelatinization compared to large ones could be related to the surface/volume ratio, which is more 188 important for small granules.

189 The behaviors of standard maize flour and starch are depicted in Fig. 9. Contrarily to flour, starch 190 swelling is very fast and occurs in one single step. As it contains very few proteins and lipids, the 191 surface network cannot be built. Consequently, the behavior of flour and starch should be different 192 in terms of transformation and processing, at least in processes with a large amount of plasticizer. In 193 plasticized starch and in plasticized starch/thermoplastic blends, where the amount of glycerol is 194 typically 33-36 wt\% (St-Pierre et al., 1997; Li and Huneault, 2011), it would be interesting to see if 195 the difference in the envelope strength can still be detected in compounding conditions. We recently 196 showed that the rheological behavior and the morphology of plasticized flour/thermoplastic blends 
197

198

were determined by the amylose/amylopectin ratio, the plasticizer content and the processing conditions, as for plasticized starch/thermoplastic blends (Deme et al., 2014).

Becker et al. (2001) studied the influence of a thermal treatment with glycerol stearate on various starches. They showed that enriched amylose starches exhibited a reduced swelling in water, contrarily to waxy maize starch which swelled even in cold water. In the present case, we investigated the effect of adding $0.2 \mathrm{~g}$ of lauric acid (corresponding to $10 \mathrm{wt} \%$ relatively to starch phase) in the standard maize starch suspension. Lauric acid is a fatty acid without insaturation, able to easily complex with amylose (Tang and Copeland, 2006). We can see in Fig. 10 that the addition of lauric acid results in a two-step swelling for the standard maize starch granules, like for flour granules. Swelling is thus delayed in presence of fatty acid, confirming the crucial role of the formation of amylose/lipid complexes at the granule surface. As expected, in the case of waxy maize flour, the effect of lauric acid is insignificant on the granule swelling (represented by the viscosity increase), as shown in Fig. 11.

Measuring swelling kinetics of the granules by optical microscopy (Fig. 6) allows us to establish a relationship between the evolution of the suspension viscosity and the one of the granule volume fraction $\phi$. The evolution of the volume fraction $\phi$ can be deduced from the evolution of the granule diameter. By introducing this volume fraction into a rheological law of suspension, it is possible to calculate the viscosity evolution with temperature. This calculation of the suspension viscosity from the knowledge of the granule size was performed although experimental conditions in which rheological and optical measurements were conducted were very different. In optical microscoscopy, the granule swelling was followed at rest and in a very dilute suspension. In rheometry, the granule swelling was followed under shear in a more concentrated medium $(6.5$ vol\%). Anyway, we tried to evaluate the viscosity evolution by using a Krieger-Dougherty equation (Krieger and Dougherty, 1959): 
$221 \quad \eta(T)=\eta_{0}(T)\left(1-\frac{\phi(T)}{\phi_{\max }}\right)^{-a}$

222 where $\eta_{0}(T)$ is the viscosity of the glycerol, $\phi_{\max }$ is the maximum packing volume fraction and $a$ is

223 an exponent, function of the maximum packing fraction and of the intrinsic viscosity of the solid 224 filler. $\phi_{\max }$ and $a$ values depend on type, shape and size polydispersity of the particles. For example, $225 \phi_{\max }=0.74$ and $\phi_{\max }=0.64$ are classical values for a suspension of rigid monodispersed spheres in 226 face centered cubic and random class packing, respectively. $a$ is often equal (or close) to 2 (see for 227 example Quemada, 2006). Fig. 12 shows that, for the standard maize flour, the model provides a 228 correct approximation of the viscosity change, despite a slight overestimation at low temperatures.

229 This prediction was obtained for $\phi_{\max }=0.52$ and $a=3$.

230 Similar calculations were performed for the other varieties of granules. The values of $\phi_{\max }$ and $a$ 231 determined for the standard maize flour suspensions were used for the viscosity estimation of the 232 other suspensions. Fig. 13 shows the comparison between experimental measurements and the 233 evolution of the viscosity using the Krieger-Dougherty law. In each case, for the different varieties 234 of flours and starch, the evolution of the solid volume fraction with temperature was calculated 235 from the experimental measurements of the granule diameter kinetics. We can see that there is quite 236 a good agreement between experimental measurements during the swelling step and the Krieger237 Dougherty prediction. This confirms that the viscosity evolution is essentially related to the granule 238 swelling and corresponding change in volume fraction.

\section{4. Conclusion.}

240 We investigated the loss of crystalline structure and swelling kinetics of various maize flours and 241 starch in excess of glycerol. Loss of crystallinity was investigated by DSC and optical microscopy. 242 Swelling kinetics was followed by optical microscopy and via viscosity measurements. 
243 The present work allowed us to highlight differences in temperature of loss of crystallinity for 244 different varieties of flours in excess of glycerol. It appears that an increased amylose content 245 makes the flours more difficult to gelatinize. This is more clearly seen in DSC measurements than 246 by observations of loss of birefringence, because a significant portion of the starch structure comes 247 not only from amylopectin crystallites but also from helical arrangements linked to amylose/lipid 248 complexes. A different effect of the heating rate on the ordered structure and on interactions 249 between glycerol and starch was evidenced.

250 We observed the same differences in swelling, because the swelling starts after gelatinization 251 occurs. Granule swelling in water depends on the amylose content, but occurs in one step. In excess 252 of glycerol, a two-step process is observed for flours containing amylose, which confirms that the 253 ghost integrity is kept by the envelope strength.

254 Swelling mechanisms in glycerol are the same as those observed in water, but the envelope 255 structure is more persistent. The strength of this envelope also comes from the formation of 256 networks including proteins, lipids and amylose. This explains the greater difficulty to deconstruct 257 granules of standard maize flour than standard maize starch, which contains much less fat and 258 protein than the flour. When processed at high level of plasticizer, flour (containing amylose) 259 should be thus more difficult to destructure than starch. Tests in presence of lauric acid highlighted 260 the role of lipids on the envelope strength.

261 These results can explain the existence of persistent "ghosts" in glycerol/flour mixtures, even at 262 high temperature, without intensive shear or addition of water.

\section{Acknowledgements}

264 This work was carried out within the project CEREMAT, supported by Céréales Vallée cluster. We 265 gratefully thank Fond Unique Interministériel (France) for financial support. The authors wish to 266 thank Professor Jean-Marc Haudin (CEMEF, MINES ParisTech) for fruitful discussions on the 
267 interpretation of the different effects of the heating rate on the shift of the exotherm and endotherm 268 temperatures.

269 


\section{References}

Becker, A., Hill, S.E., Mitchell, J.R., 2001. Relevance of amylose-lipid complexes to the behaviour of thermally processed starches. Starch/Stärke, 53, 121-130.

Blazek, J., Copeland, L., 2008. Pasting and swelling properties of wheat flour and starch in relation to amylose content. Carbohydr. Polym., 71, 380-387.

Blazek, J., Copeland, L., 2009. Effect of monopalmitin on pasting properties of wheat starches» with varying amylose content. Carbohydr. Polym., 78, 131-136.

Chang, F., He, X., Huang, Q., 2013. The physicochemical properties of swelled maize starch granules complexed with lauric acid. Food Hydrocoll., 32, 365-372.

Chen, P., Yu, L., Kealy, T., Chen, L., Li, L., 2007. Phase transition of starch granules observed by microscope under shearless and shear conditions. Carbohydr. Polym., 68, 495-501.

Chen, P., Yu, L., Simon, G.P., Liu, X., Dean, K., Chen, L., 2011. Internal structure and phase transitions of starch granules during gelatinization. Carbohydr. Polym., 83, 1975-1983.

Cooke, D., Gidley, M.J., 1992. Loss of crystalline and molecular order during starch gelatinisation: origin of the enthalpic transition. Carbohydr. Res., 227, 103-112.

Debet, M.R., Gidley, M.J., 2006. Three classes of starch granule swelling: Influence of surface proteins and lipids. Carbohydr. Polym., 64, 452-465.

Debet, M.R., Gidley, M.J., 2007. Why do gelatinized starch granules not dissolve completely? Roles for amylose, protein, and lipid in granule "ghost" integrity". J. Agric. Food Chem., 55, $4752-4760$.

Demé, F., Peuvrel-Disdier, E. Vergnes, B., 2014. Rheology and morphology of polyester/thermoplastic flour blends. J. Appl. Polym. Sci., 131, 40222

Donovan J.W., 1979. Phase transitions of starch water system. Biopol., 18, 263-275. 
Eliasson, A.C., 1986. Viscoelastic behavior during the gelatinization of starch. I. Comparison of wheat, maize, potato and waxy-barley starches. J. Text. Stud., 17, 253-265.

Forssell, P.M., Mikkila, J.M., Moates, G.K., Parker, R., 1997. Phase and glass transition behaviour of concentrated barley starch-glycerol-water mixtures, a model for thermoplastic starch. Carbohydr. Polym., 34, 275-282.

Fredriksson, H., Silverio, J., Andersson, R., Eliasson, A.C., Aman, P., 1998. The influence of amylose and amylopectin characteristics on gelatinization and retrogradation properties of different starches. Carbohydr. Polym., 35, 119-134.

Habeych, E., Guo, X., Van Soest, J.J.G., Van der Goot, A.J., Boom, R., 2009. On the applicability of Flory-Huggins theory to ternary starch-water-solute systems. Carbohydr. Polym., 77, 703712.

Habitante, A.M.B.Q., Sobral, P.J.A., Carvalho, R.A., Solorza-Feria, J., Bergo, P.V.A., 2008. Phase 305 transitions of cassava starch dispersions prepared with glycerol solutions. J. Thermal Anal. Cal., 93, 599-604.

Jenkins, P.J., Donald, A.M., 1998. Gelatinisation of starch: A combined SAXS/WAXS/DSC and SANS study. Carbohydr. Res.,308, 133-147.

Koganti, N., Mitchell, J.R., MacNaughtan, W., Hill, S., Foster, T., 2015. Effect of granule organization on the behavior of starches in the NMMO (N-methyl morpholine $\mathrm{N}$-oxide) solvent system. Carbohydr. Polym., 116, 103-110.

313 gelatinization. Biomacromol., 12, 2888-2893.

314 Krieger, I.M., Dougherty, T.J., 1959. A mechanism for non-Newtonian flow in suspensions of rigid 315 spheres. Trans. Soc. Rheol., 3, 137-152. 
Li, G., Sarazin, P., Favis, B.D., 2008. The relationship between starch gelatinization and morphology control in melt-processed polymer blends with thermoplastic starch. Macromol. Chem. Phys., 209, 991-1002.

Li, G., Favis, B.D., 2010. Morphology development and interfacial interactions in polycaprolactone / thermoplastic starch blends. Macromol. Chem. Phys, 211, 321-333.

Li, H., Huneault, M.A., 2011. Comparison of sorbitol and glycerol as plasticizers for thermoplastic starch in TPS/PLA blends. J. Appl. Polym. Sci., 119, 2439-2448.

Liu, H., Yu, L., Xie, F., Chen, L., 2006. Gelatinization of cornstarch with different amylose/amylopectin content. Carbohydr. Polym., 65, 357-363.

Liu, H., Xie, F., Li, M., Liu, X., Yu, L., Halley, P.J., Chen, L., 2011. Phase transitions of maize starches with different amylose contents in glycerol-water systems. Carbohydr. Polym., 85, 180-

Mateyawa, S., Xie, D.F., Truss, R.W., Halley, P.J., Nicholson, T.M., Shamshina, J.L., Rogers, R.D., Boehm, M.W., McNally, T., 2013. Effect of the ionic liquid 1-ethyl-3-methylimidazolium acetate on the phase transition of starch: dissolution or gelatinization? Carbohydr. Polym., 94,

Matveev, Y.I., Van Soest, J.J.G., Nieman, C., Wasserman, L.A., Protserov, V.A., Ezernotskaja, M., Yuryev, V.P., 2001. The relationship between thermodynamics and structural properties of low and high amylose maize starches. Carbohydr. Polym., 44, 151-160.

Nashed, G., Rutgers, R.P.G., Sopade, P.A., 2003. The plasticization effect of glycerol and water on the gelatinisation of wheat starch. Starch/Stärke, 55, 131-137.

Olkku, J., Rha, C., 1978. Gelatinization of starch and wheat flour starch - a review. Food Chem., 3, $293-317$. 
339 Patel, B.K., Seetharaman, K., 2006. Effect of heating rate on starch granule morphology and size. $340 \quad$ Carbohydr. Polym., 65, 381-385.

341 Quemada, D., 2006. Modélisation Rhéologique Structurelle, Lavoisier, Paris.

342 Ratnayake W.S., Jackson, D.S., 2006. Gelatinization and solubility of corn starch during heating in 343 excess water: new insights. J. Agr. Food Chem., 54, 3712-3716.

344 Rodriguez-Gonzalez, F.J., Ramsay, B.A., Favis, B.D., 2003. High performance LDPE/thermo345 plastic starch blend: a sustainable alternative to pure polyethylene. Polymer, 44, 1517-1526.

346 Russell, P.L., 1987. Gelatinisation of starches with different amylose/amylopectin content. A study 347 by differential scanning calorimetry. J. Cereal Sci., 6, 133-145.

348 Sopade, P.A., Halley, P.J., Junming, L.L., 2004. Gelatinisation of starch in mixtures of sugars. II. 349 Application of differential scanning calorimetry. Carbohydr. Polym., 58, 311-321.

350 St-Pierre, N., Favis, B.D., Ramsay, B.A., Ramsay, J.A., Verhoogt, H., 1997. Processing and 351 characterization of thermoplastic starch/polyethylene blends. Polymer, 38, 647-655.

352 Sasaki, T., Matsuki, J., 1998. Effect of wheat starch structure on swelling power, Cereal Chem., 75, $353 \quad 525-529$.

354 Smits, A.L.M., Kruiskamp, P.H., Van Soest, J.J.G, Vliegenthart, J.F.G., 2003. Interaction between 355 dry starch and plasticisers glycerol or ethylene glycol, measured by differential scanning 356 calorimetry and solid state NMR spectroscopy. Carbohydr. Polym., 53, 409-416.

357 Spigno, G., Dante, M., Faveri, D., 2004. Gelatinization kinetics of rice starch studied by non358 isothermal calorimetric technique: influence of extraction method, water concentration and 359 heating rate. J. Food Eng., 62, 337-344. 
360 Tan, I., Wee, C.C., Sopade, P.A., Halley, P.J., 2004. Investigation of the starch gelatinization 361 phenomena in water-glycerol systems: application of modulated temperature differential 362 scanning calorimetry. Carbohydr. Polym., 58, 191-204.

363 Tan, I., Torley, P.J., Halley, P.J., 2008. Combined rheological and optical investigation of maize, 364 barley and wheat starch gelatinisation. Carbohydr. Polym., 72, 272-286.

365 Tang, M.C., Copeland, L., 2006. Analyses of complexes between lipids and wheat starch. 366 Carbohydr. Polym., 67, 80-85.

367 Tester, R.F., Morrison, W.R., 1990. Swelling and gelatinization of cereal starches. Cereal Chem., $368 \quad 67,551-557$.

369 Tester, R.F., Debon, S.J.J., Sommerville, M.D., 2000. Annealing of maize starch, Carbohydr. $370 \quad$ Polym., 42, 287-299.

371 Tester, R.F., Karkalas, J., Qi, X., 2004. Starch composition, fine structure and architecture, J. Cereal 372 Sci., 39, 151-165.

373 Van Soest, J.J.G., Bezemer, R.C., de Wit, D., Vliegenthart, J.F.G., 1996. Influence of glycerol on 374 melting of potato starch. Ind. Crops Prod., 5, 1-9.

375 Wootton, M., Bamunuarachchi, A., Application of differential scanning calorimetry to starch 376 gelatinization. Starch/Stärke, 31, 262-264.

377 Yang, W.H., Rao, M.A., 1998. Complex viscosity-temperature master curve of cornstarch 378 dispersion during gelatinization. J. Food Proc. Eng., 21, 191-207.

379 Yu, L., Kealy, T., Chen, P., 2006. Study of starch gelatinization in a flow field using simultaneous 380 rheometric data collection and microscopic observations. Intern. Polym. Proc., 21, 283-289.

381 Zanoni, B., Schiraldi, A., Simonetta, R., 1995. Naive model of starch gelatinization kinetics. J. 382 Food Eng., 24, 25-33. 
Fig. 1. SEM micrographies of the pristine granules. (a) standard maize flour, (b) waxy maize flour, (c) high amylose maize flour, (d) standard maize starch. The white spots on the flour pictures correspond to minerals (calcium, magnesium, phosphorus) ( 0.5 to $1.3 \mathrm{wt} \%$ on dry basis)

Fig. 2. Optical observation of the swelling of granules of flour suspended in glycerol versus temperature: (a) to (c) between crossed polarizers, (d) to (f) without polarizers, heating rate of $5^{\circ} \mathrm{C} / \mathrm{min}$.

Fig. 3. DSC thermograms (endo up) of a glycerol/maize starch suspension during first and second heating at $5^{\circ} \mathrm{C} / \mathrm{min}$. Thermograms were vertically shifted for sake of clarity.

Fig. 4. Variation of temperatures corresponding to endothermal and exothermal peaks with the heating rate of a glycerol/maize starch suspension.

Fig. 5. Effect of the maturation time on the exothermal peak of a glycerol/maize starch suspension $\left(5^{\circ} \mathrm{C} / \mathrm{min}\right)$. Thermograms were vertically shifted for more clarity.

Fig. 6. Evolution of the granule diameter with temperature for a standard maize flour in glycerol at $10^{\circ} \mathrm{C} / \mathrm{min}$ : case of small and large granules.

Fig. 7. Effect of heating rate on the viscosity evolution with temperature of a standard maize flour suspension in glycerol: $\bullet: 1^{\circ} \mathrm{C} / \mathrm{min}, \triangle: 5^{\circ} \mathrm{C} / \mathrm{min}, ~ \bigcirc: 10^{\circ} \mathrm{C} / \mathrm{min}$.

Fig. 8. Effect of amylose content on the viscosity evolution with temperature $\left(10^{\circ} \mathrm{C} / \mathrm{min}\right)$ of maize flour suspensions in glycerol:

•: standard maize, $\bigcirc$ : waxy maize, $\triangle$ : high amylose maize.

Fig. 9. Evolution of the viscosity with temperature $\left(10^{\circ} \mathrm{C} / \mathrm{min}\right)$ of standard maize flour $(\bullet)$ and starch (O) suspensions in glycerol. 
408 Fig. 10. Influence of lauric acid on the viscosity evolution with temperature $\left(10^{\circ} \mathrm{C} / \mathrm{min}\right)$ of standard maize starch in glycerol excess $(\bullet$ : starch, $\bigcirc$ : starch with lauric acid).

410 Fig. 11. Influence of lauric acid on the viscosity evolution with temperature $\left(10^{\circ} \mathrm{C} / \mathrm{min}\right)$ of waxy 411 maize flour in glycerol excess ( $\bullet$ : waxy maize flour, $\bigcirc$ : waxy maize flour with lauric acid).

412 Fig. 12. Viscosity evolution with temperature $\left(10^{\circ} \mathrm{C} / \mathrm{min}\right)$ of standard maize flour suspension in 413 glycerol. Comparison between experiment $(\bigcirc)$ and model $(-)$.

414 Fig. 13. Viscosity evolution with temperature $\left(10^{\circ} \mathrm{C} / \mathrm{min}\right)$ of flour and starch suspensions in glycerol. Comparison between experiment (symbols) and model (lines).,,- : waxy maize flour, $\square,-$ : high amylose maize flour, $\bullet, \ldots$.-- : standard maize starch. 


\begin{tabular}{ccccc}
\hline & $\begin{array}{c}\text { Standard } \\
\text { maize starch }\end{array}$ & $\begin{array}{c}\text { Standard } \\
\text { maize flour }\end{array}$ & $\begin{array}{c}\text { Waxy } \\
\text { maize flour }\end{array}$ & $\begin{array}{c}\text { High amylose } \\
\text { maize flour }\end{array}$ \\
\hline Raw density (g/L) & 1470 & 1407 & 1449 & 1420 \\
\hline Amylose (wt\%) & 30 & 30 & 1 & 70 \\
\hline Water (wt\%) & 12.27 & 8.76 & 8.39 & 9.44 \\
\hline Proteins (wt\%) & 0.4 & 8.33 & 9.16 & 9.8 \\
\hline Lipids $(\mathrm{wt} \%)$ & 0.92 & 2.9 & 1.66 & 5.49 \\
\hline Ashes at $900^{\circ} \mathrm{C}(\mathrm{wt} \%)$ & 0.06 & 0.9 & 0.53 & 1.29 \\
\hline
\end{tabular}

Table 1 . Starchy products density and composition (in weight $\%$ of dry matter). Data provided by ULICE 


\begin{tabular}{cccccccc}
\hline & \multicolumn{3}{c}{ Microscopy } & \multicolumn{3}{c}{ DSC } \\
\hline & $\begin{array}{c}T_{\text {onset }} \\
\left({ }^{\circ} \mathrm{C}\right)\end{array}$ & $\begin{array}{c}T_{\text {end }} \\
\left({ }^{\circ} \mathrm{C}\right)\end{array}$ & $\begin{array}{c}T_{\text {average }} \\
\left({ }^{\circ} \mathrm{C}\right)\end{array}$ & $\begin{array}{c}T_{\text {onset }} \\
\left({ }^{\circ} \mathrm{C}\right)\end{array}$ & $\begin{array}{c}T_{\text {end }} \\
\left({ }^{\circ} \mathrm{C}\right)\end{array}$ & $\begin{array}{c}T_{\text {average }} \\
\left({ }^{\circ} \mathrm{C}\right)\end{array}$ & $\begin{array}{c}\text { Enthalpy } \\
(\mathrm{J} / \mathrm{g})\end{array}$ \\
\hline $\begin{array}{c}\text { Standard maize } \\
\text { starch }\end{array}$ & 129 & 143 & 136 & 100 & 140 & 121 & 4,1 \\
\hline $\begin{array}{c}\text { Standard maize } \\
\text { flour }\end{array}$ & 128 & 137 & 132 & 113 & 159 & 127 & 4,9 \\
\hline $\begin{array}{c}\text { Waxy maize } \\
\text { flour }\end{array}$ & 123 & 133 & 128 & 110 & 148 & 130 & 2,4 \\
\hline $\begin{array}{c}\text { High amylose } \\
\text { maize flour }\end{array}$ & 130 & 150 & 140 & 110 & 175 & 145 & 6,0 \\
\hline
\end{tabular}

Table 2. Temperatures of loss of birefringence (microscopy) and gelatinization (DSC) of starch and flour granules in glycerol excess. 


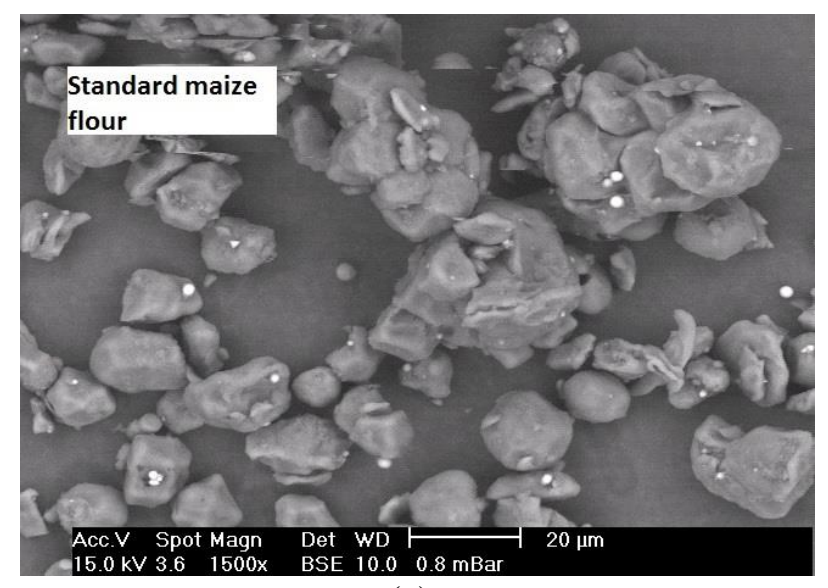

(a)

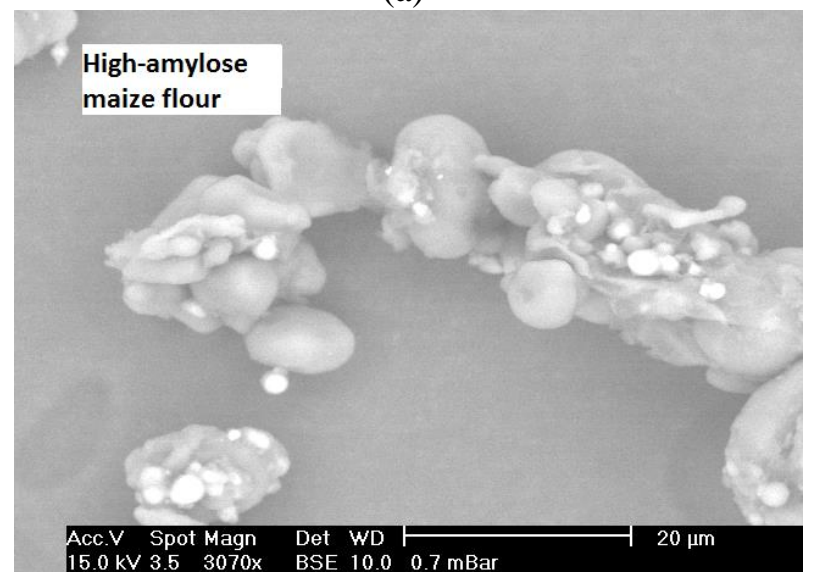

(c)

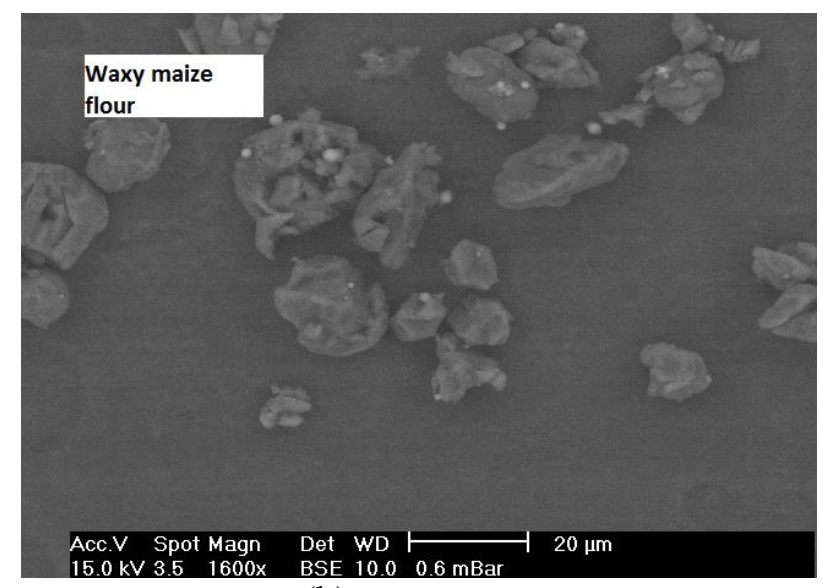

(b)

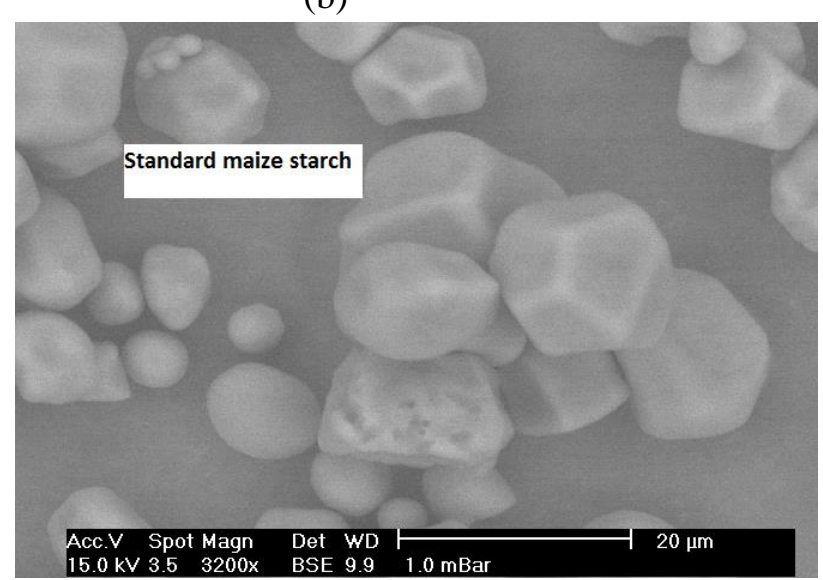

(d)

Fig. 1. Demé et al. 


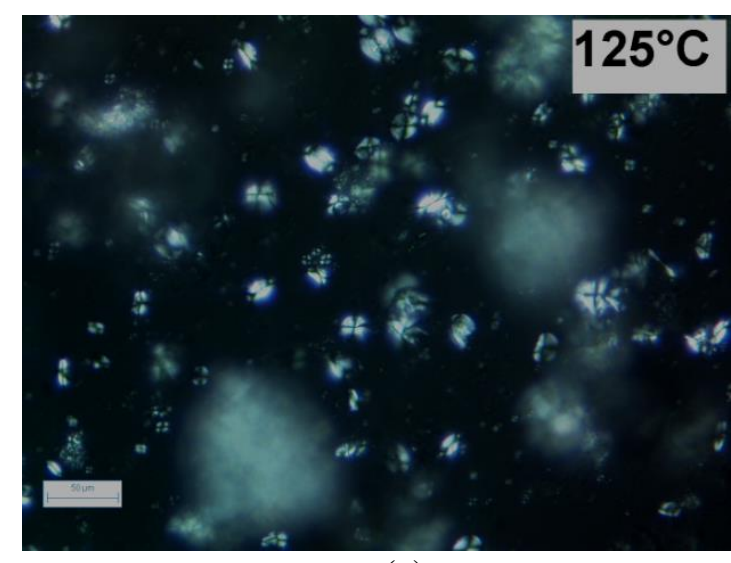

(a)

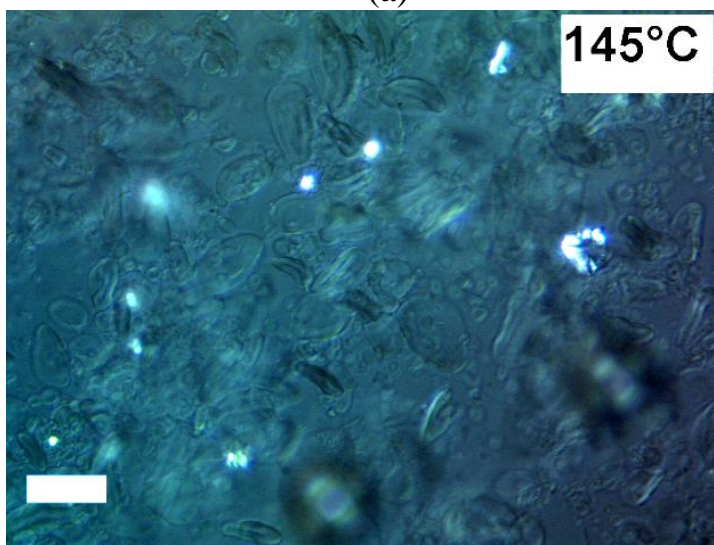

(c)

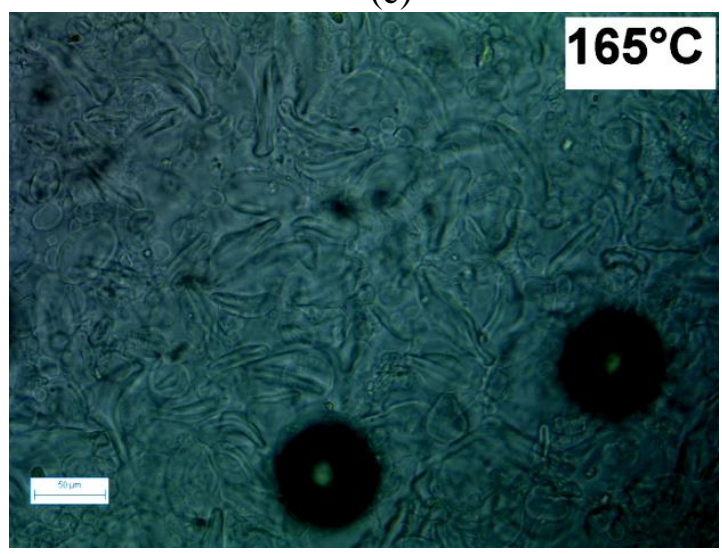

(e)

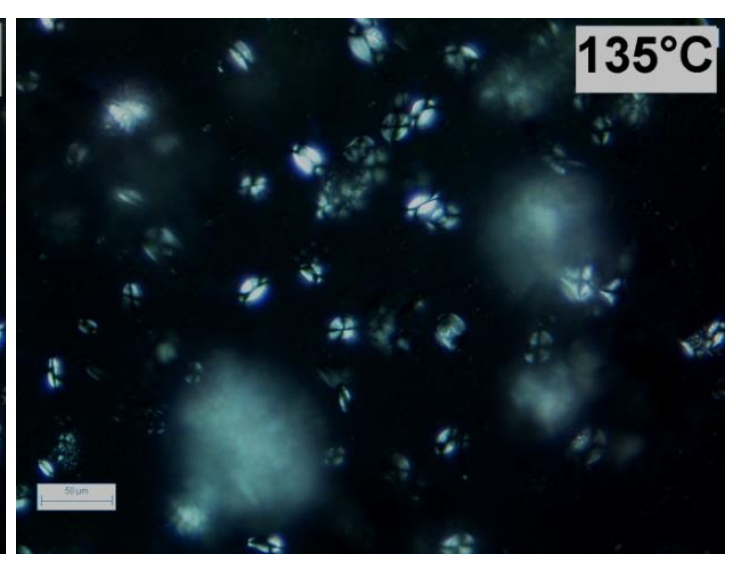

(b)

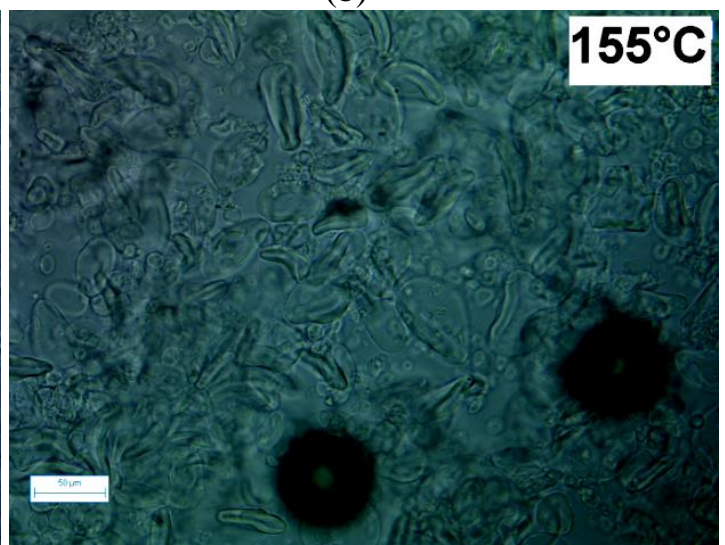

(d)

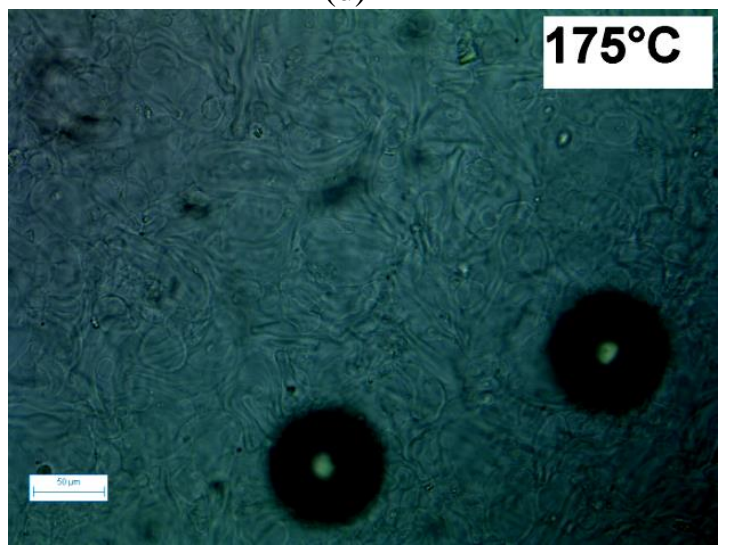

(f)

Fig. 2. Demé et al. 


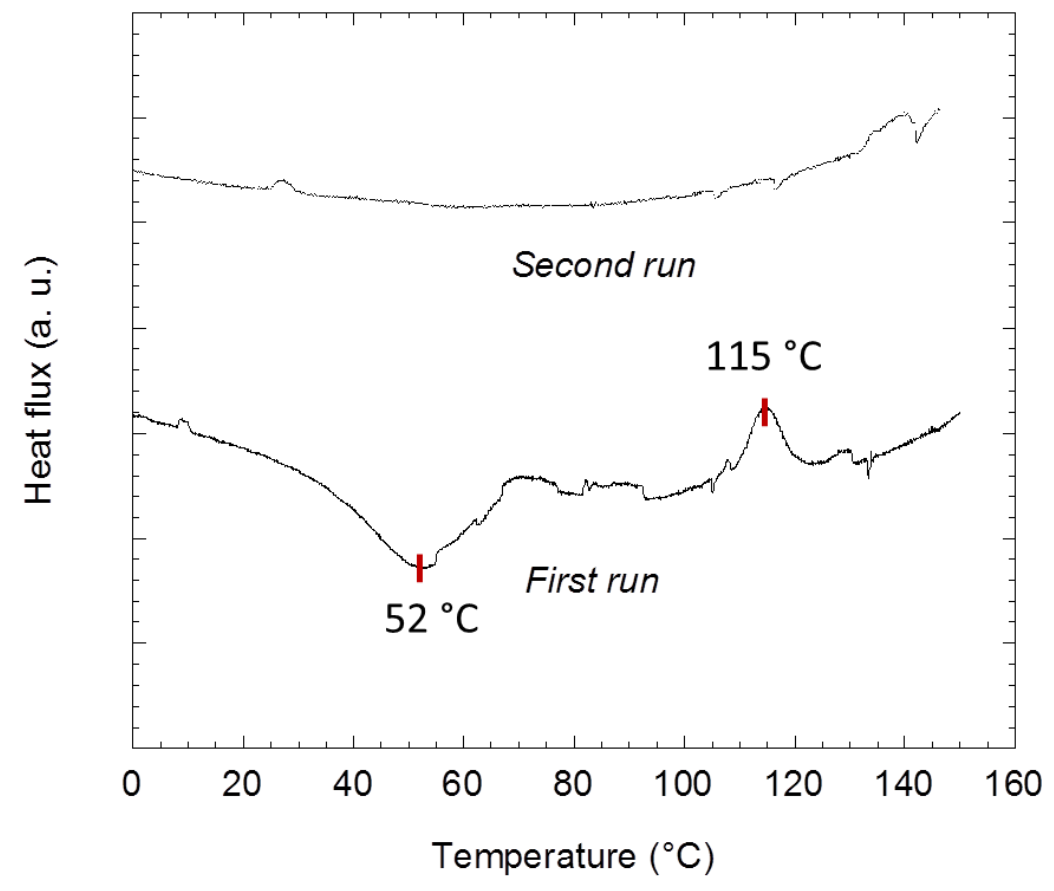

Fig. 3. Demé et al. 


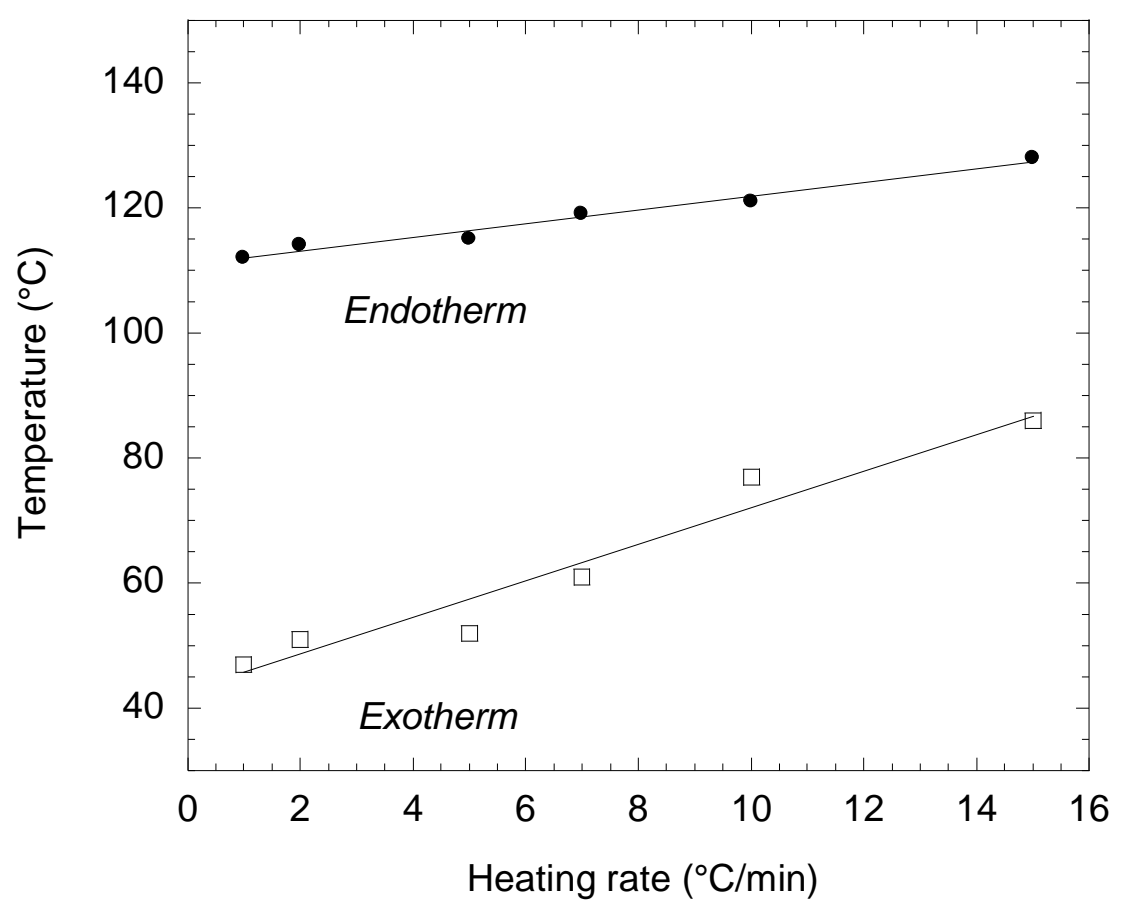

Fig. 4. Demé et al. 


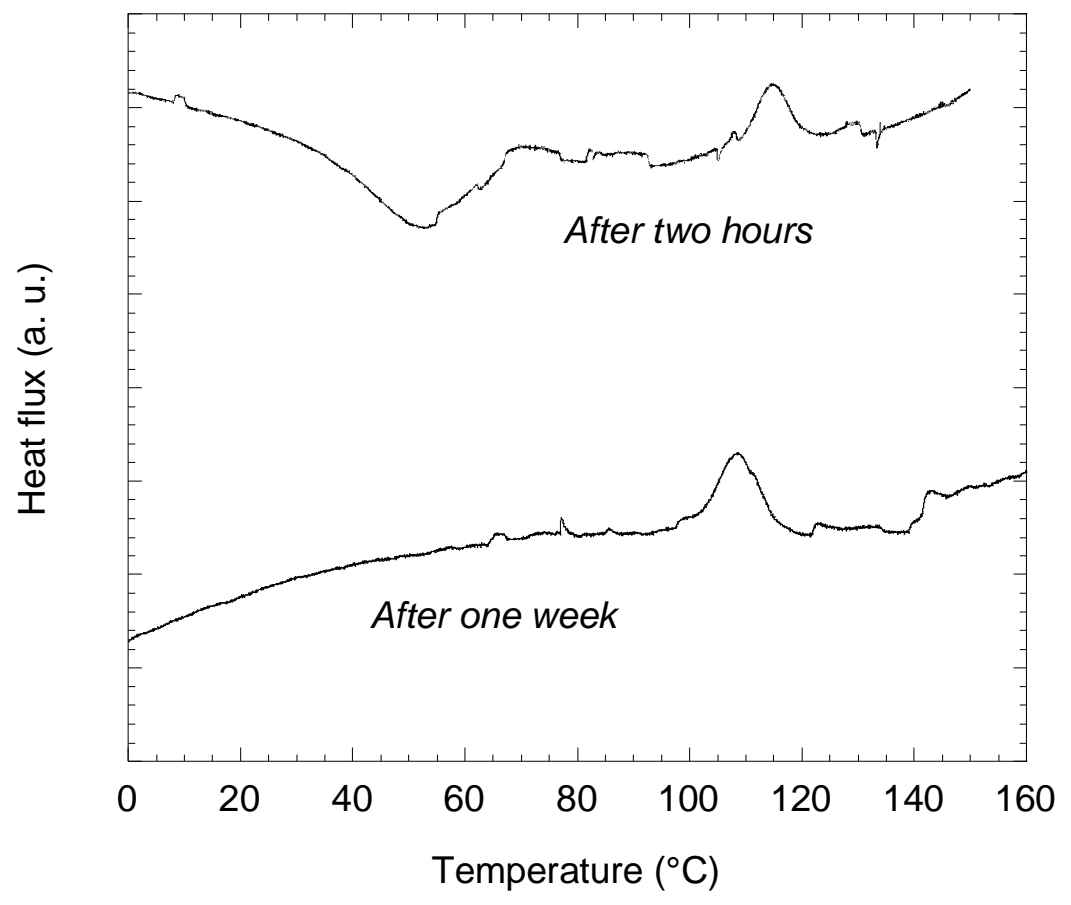

Fig. 5. Demé et al. 


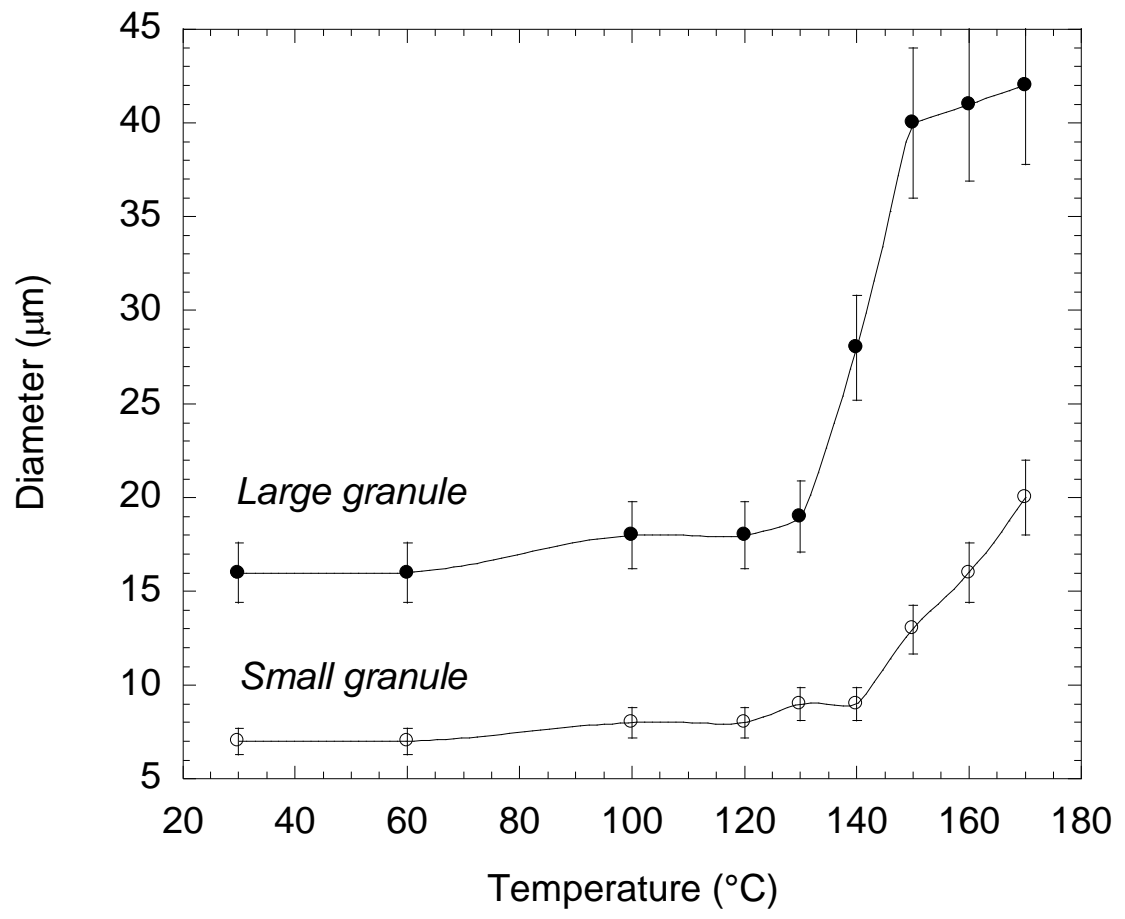

Fig. 6. Demé et al. 


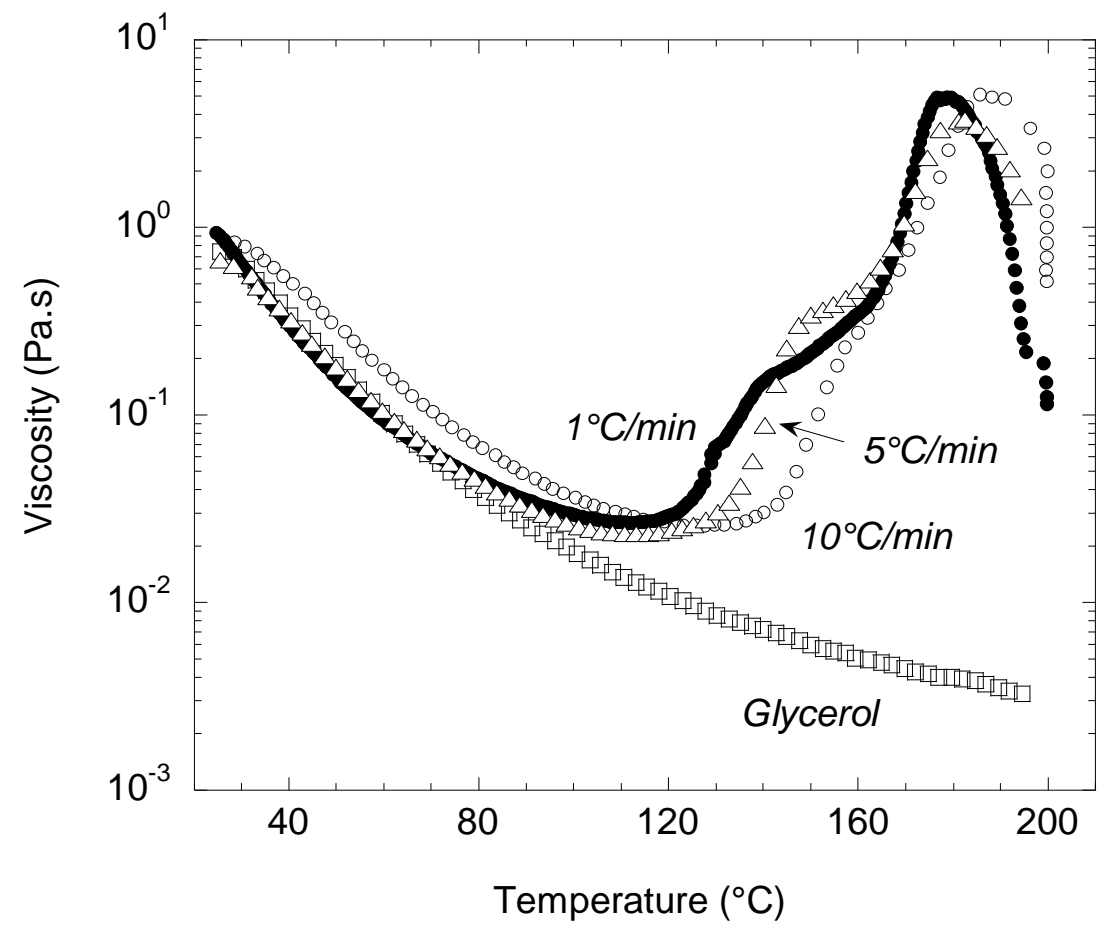

Fig. 7. Demé et al. 


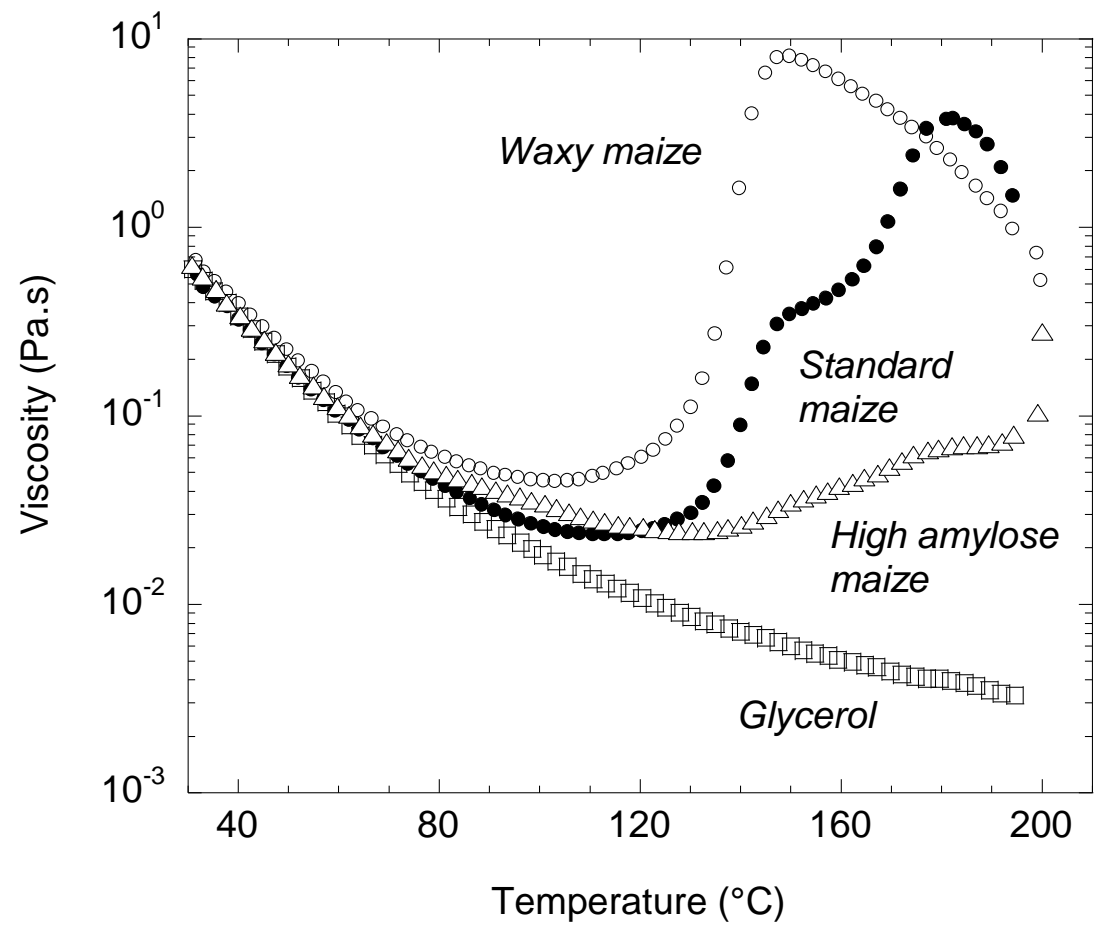

Fig. 8. Demé et al. 


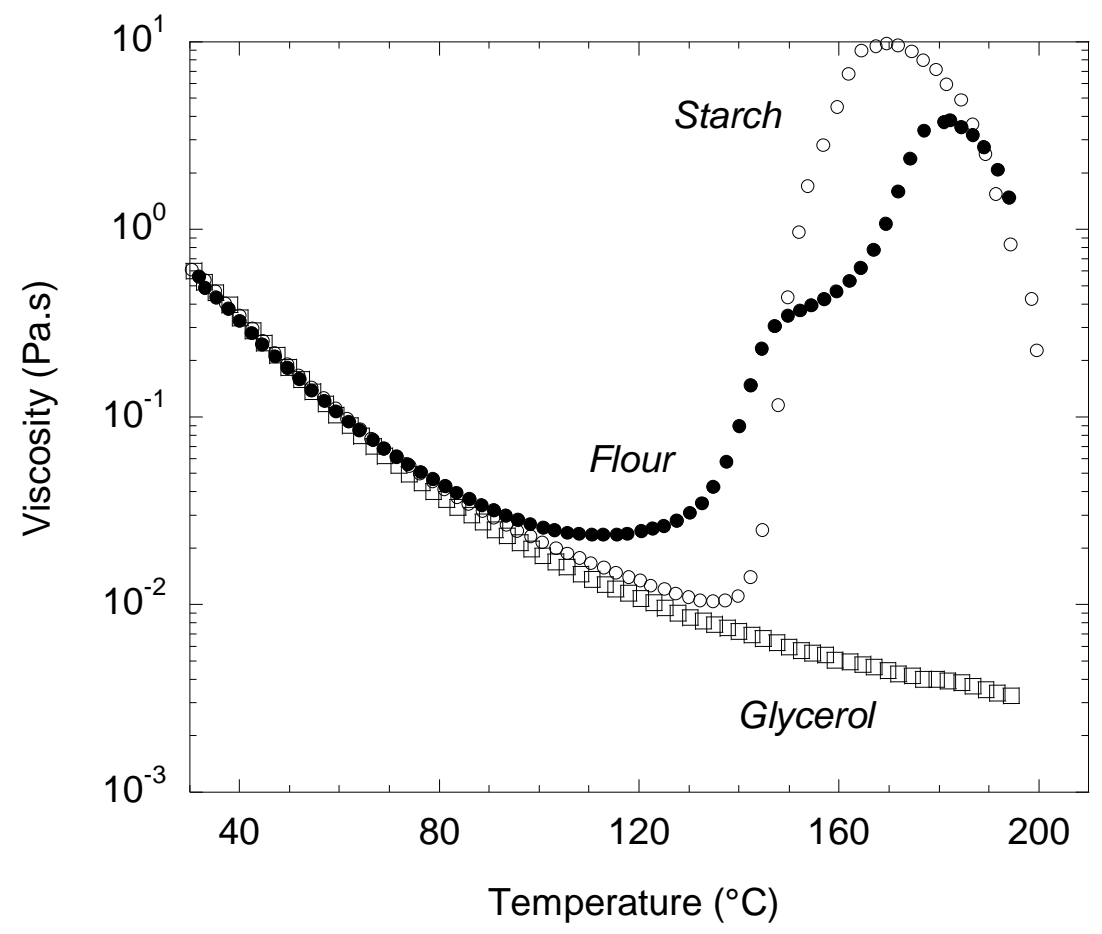

Fig. 9. Demé et al. 


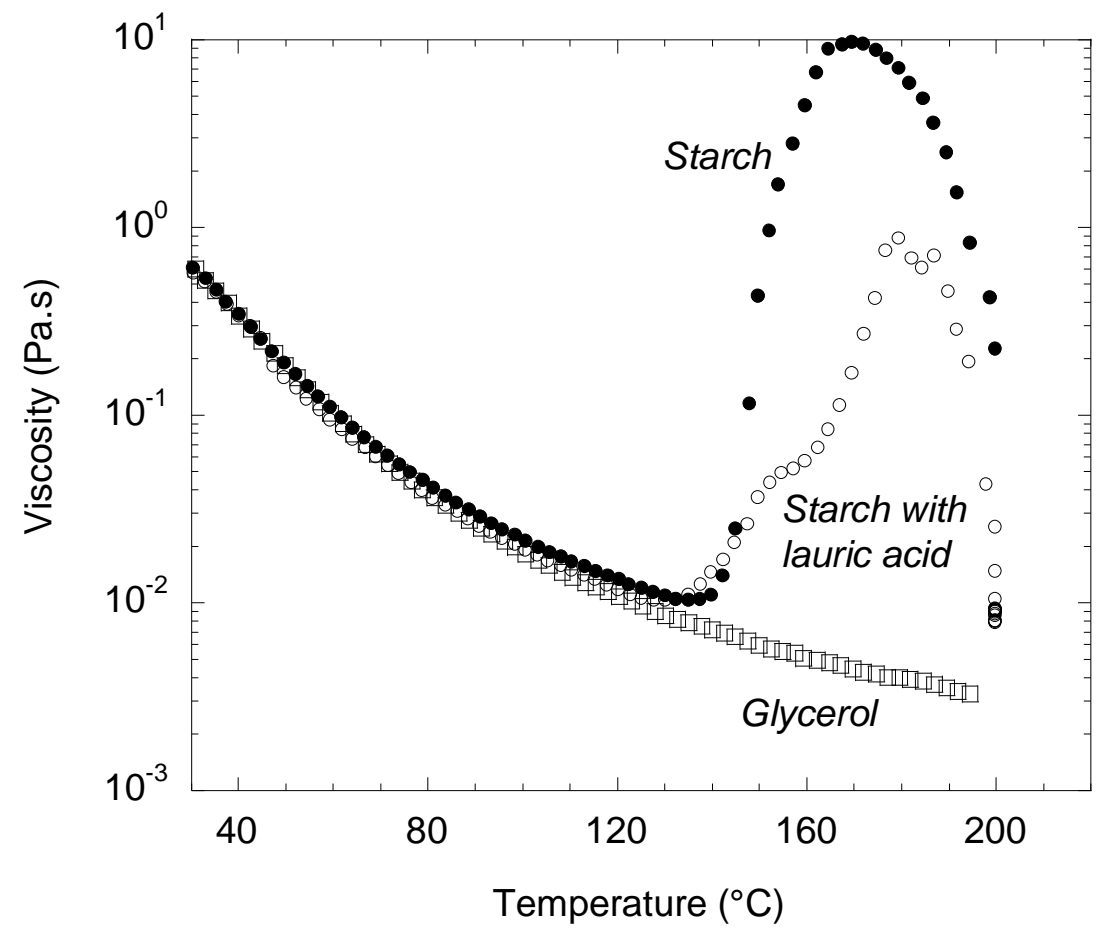

Fig. 10. Demé et al. 


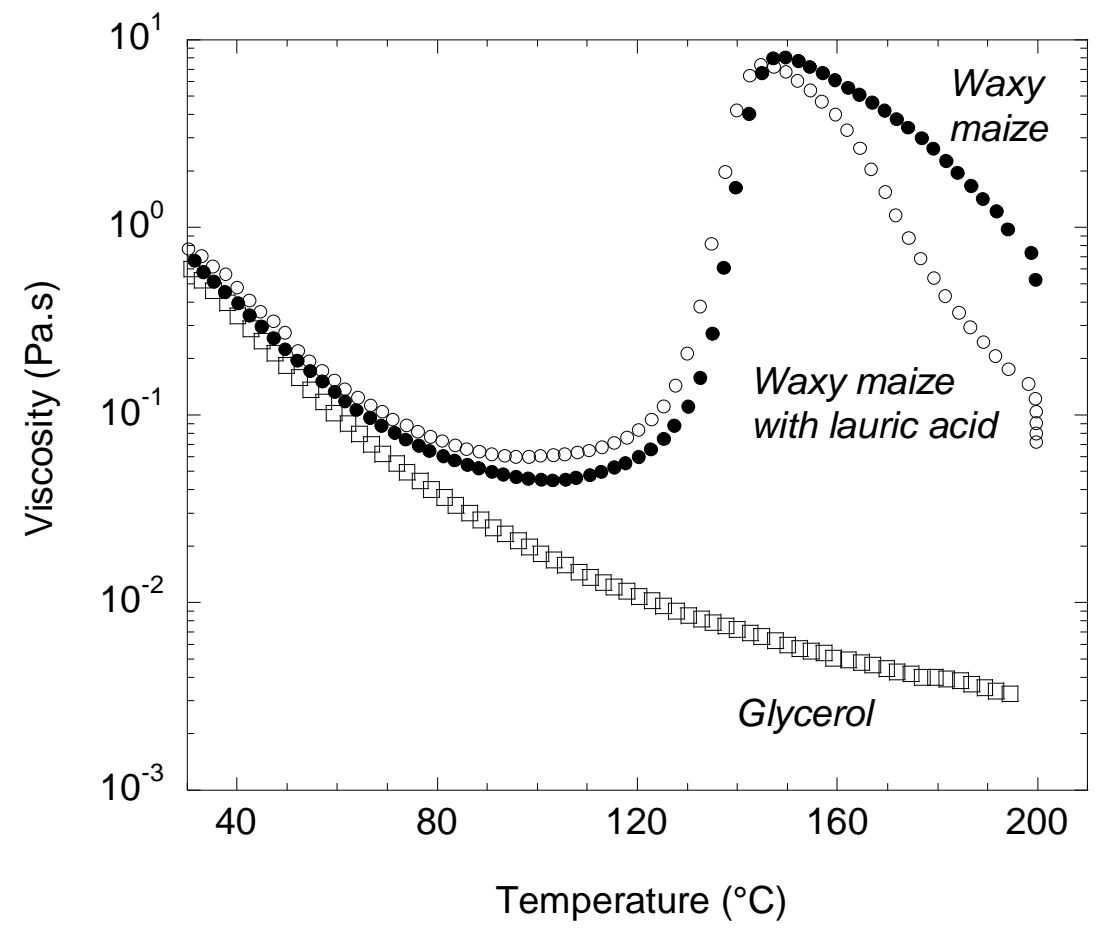

Fig. 11. Demé et al. 


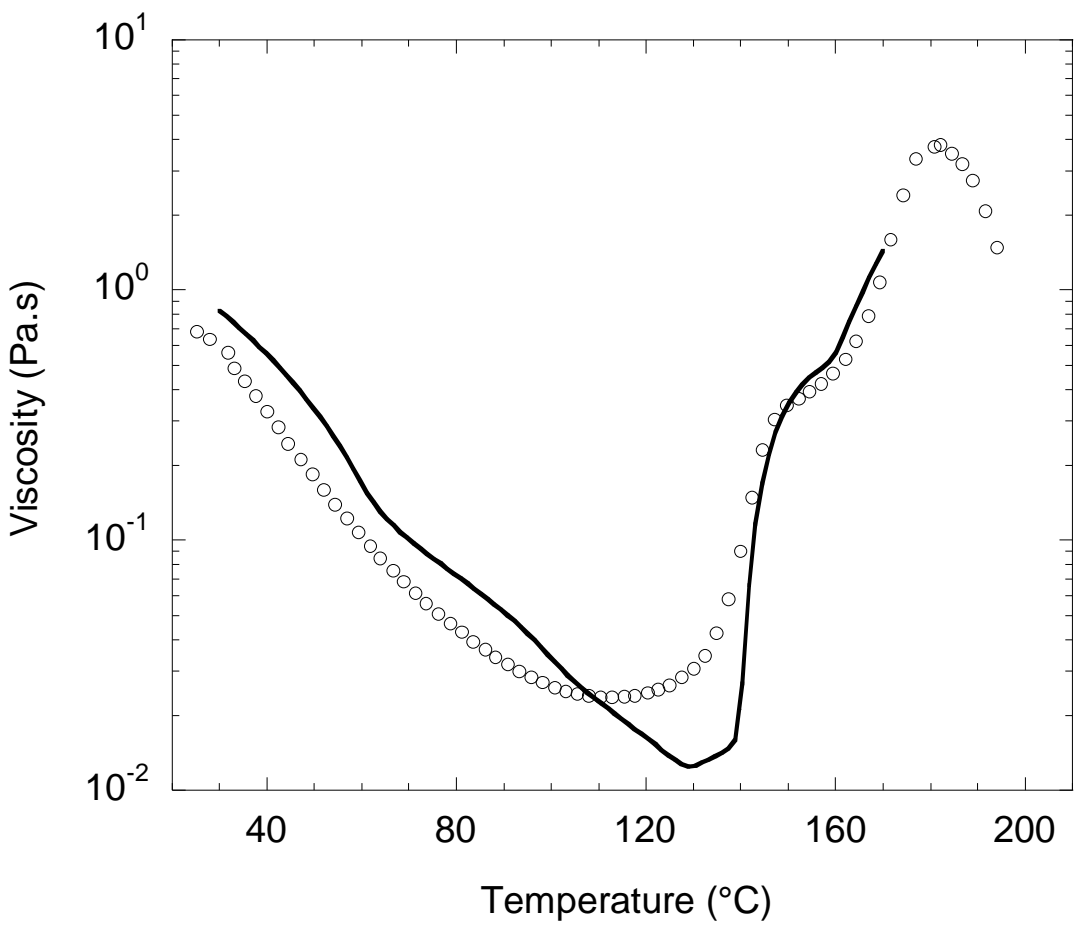

Fig. 12. Demé et al. 


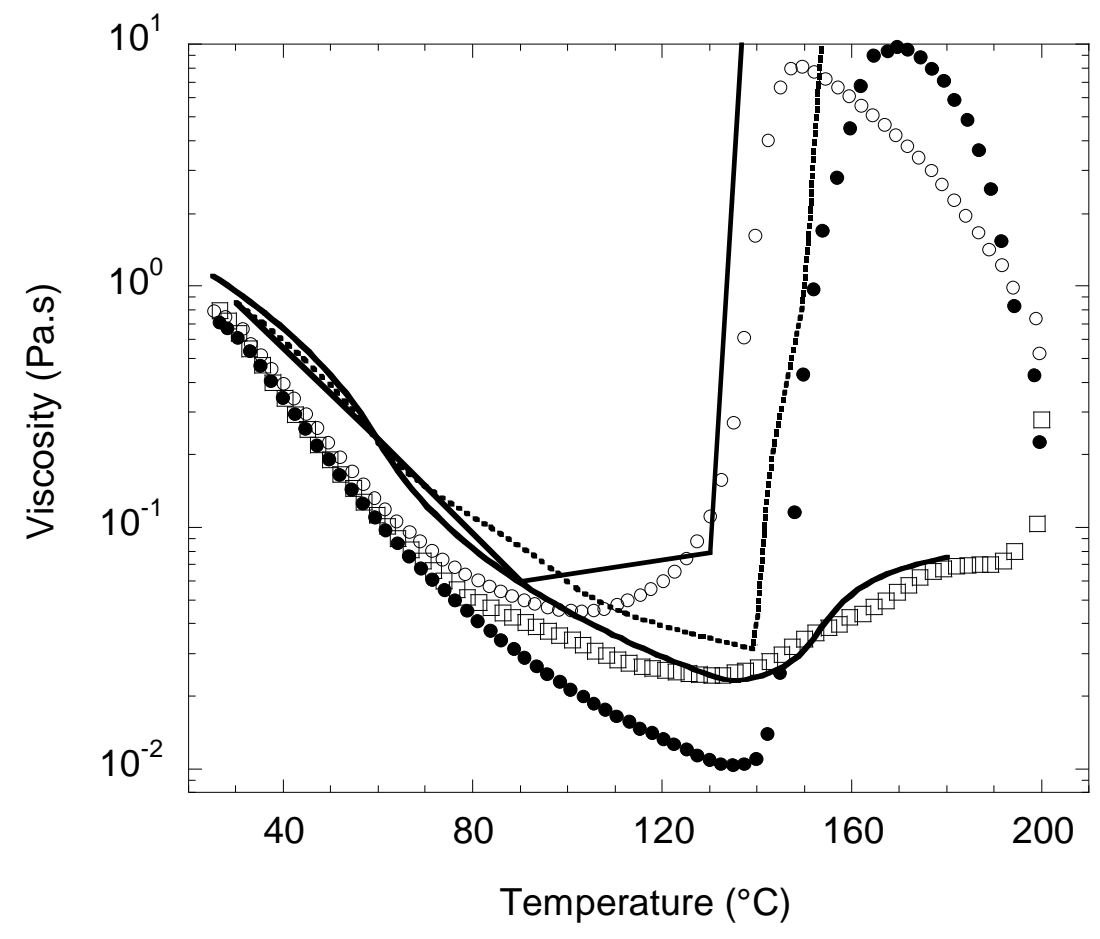

Fig. 13. Demé et al. 